\title{
岡山藩の干拓地における石造愑門
}

\section{Stone Sluices constructed in Reclaimed Area of Okayama Clan}

樋口輝久* 一需場俊介**

By Teruhisa HIGUCHI and Shunsuke BABA

\begin{abstract}
Stone sluices composed by huge granite blocks were a kind of trademark in the reclaimed area of Okayama clan. They were introduced to Okayama clan and were spread out by masonry technocrat invited from Osaka area. This paper try to describe the development of the stone sluices based on the field and bibliographical survey. History of stonemasons, famous Jihei Kawachiya is also shown from a viewpoint of contributor for the construction of stone sluices.
\end{abstract}

\section{1.はじめに}

現代のように標準化·画一化される前の土木構造物は、そ れぞれに地域独自の個性を持っていた。その個性こそが、今 後の社会基盤整備を進める上で重要なキーワードになる「地 域性」である。著者らは、岡山の広大な干拓地に残る江戸期 から昭和戦前期に至る農業用樋門 以、岡山藩の石工が得意と した「巻石」構造物 2)について研究を進めてきたが、荒削り な風貌を持つ近世の巨石旋門は「岡山の地域性」を彩る最 も重要な資産と言える。

巨石硧門が岡山で数多く造られた直接的原因は、良質の 花崗岩が児島湾や犬島など瀨戸内沿岸で大量に産出し、そ れらを石切場から干拓地まで容易に海上翰送できたためで ある。花㒸岩が曲げ強度の高い材料であったが故に、石材を 木梁や木柱のように使った独特の構造も生まれた。間接的 原因としては、吉井·地・高梁の三川が流出する土砂の堆積 作用によって新田開発に適した地形を巧みに利用して、普請 事業を積極的に進めた岡山藩の政策が挙げられる。こうした 自然条件·社会条件を背景にして、花蓇岩の巨石でタテリ （柱）と笠木 (梁) を大胆に組み合わせた井桁構造の巨石樋 門が江戸期を通じて筑造された。

岡山藩は江戸初期から新田開発を進めてきたが、17 世紀 後半からの藩営による干拓事業は、その規模·技術において、 わが国の近世を代表する干拓事業の一つと言われている。 この大規模な干拓を可能にした背詈には、石造樋鹏の早期導 入があった。干拓地において悪水処理は重要な問題で、安 定して排水するためには耐久珄のある樋門が要求されたの である。岡山と同じように大規模な干拓が行われた熊本の
八代湾でも広範围に石造樋門が用いられているが、それらは 19 世紀前半に備前石工によって伝授されたものであった。

岡山藩の藩政史料である池田家文庫 (岡山大学付属図書館 所蔵)の整理·分析により藩の歴史が解明される中で、普請事 業・石工に関しても徐々に明らかになってきた。しかし、人物 顕彰への熱意とは逆に構造物自体への地元の関心は嵪くな く、近世の石造樋門が広大な干拓地に残されていたにもかか わらず (昭和期)、多くの石造樋門が解体され、現在もその 姿勢は变わらない。本論文の目的は、現存している石造杼門 と史料の双方を参照して石造樋門の客観的評価を行い、保 存·活用の推進への一助とするものである。

本論文では、2章で、石造樋門の実態調査とその分析を行 いっいで3章で、石造樋門の構築者 (石工)に関する史料 分析を行う。なお、同時期に、備中 (倉數市周辺) でも、高梁 川下流域の新田開発で多くの石造桶門が造られたが (形態 的にも岡山藩のものと似ている)、ここで海岡山藩の領地で あった備前に限定して分析を進める。

\section{2. 石造杼門の実態調查とその分析}

本章では、現存もしくは近年まで残っていた石造嗵門の実 態調査を行い、それらが史料上どのように記されているがを 確認するとともに、それらから読み取れる各種の技術的指標 を明らかにしようとする。すなわち、(1)節では、岡山藩の石 造樋門を、a)初期と b)盛期の二つに分け、それぞれ、地域ご とにそれらがどのようなものであったかを、史料を交えて再 構成する。(2)節では、技術的な視点、すなわち、a)㙆板開闒 方式、b)大型化、c)基嘫工の三点について詳細に分析する。
Keywords：樋門，花嵐岩，石工。干拓

（干700-8530 岡山市津島中 3-1-1）
* 正会員 岡山大学助手 (環境理工学部環境デザイン工学科)

**正会員岡山大学教授(同上) 


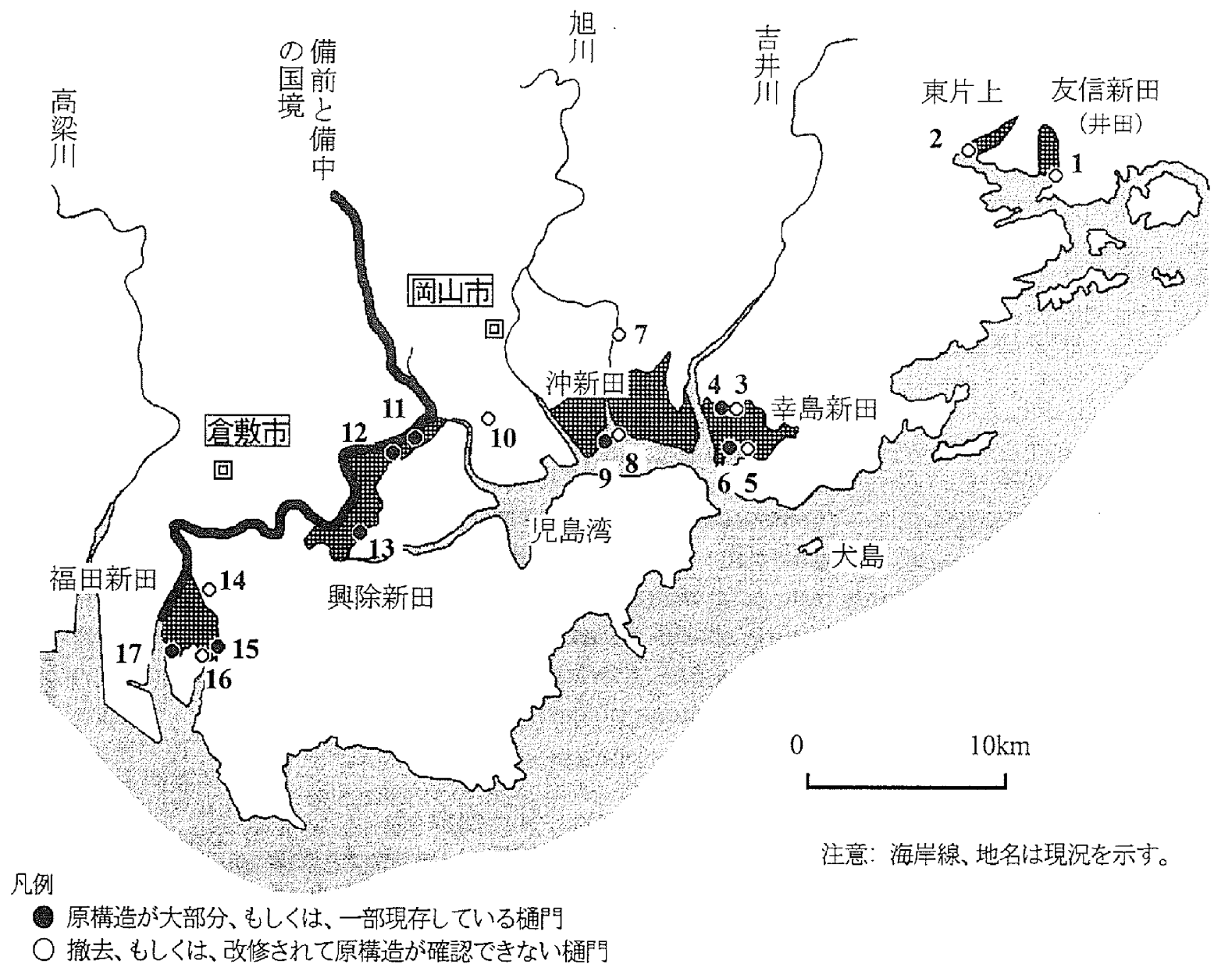

樋門の名称（一地域に集中している場合は、一つの記号で代表させている）

\begin{tabular}{|c|c|c|c|}
\hline $\begin{array}{l}\text { 1, 井田の大桶·小樋 } \\
\text { 2, 東片上の潮樋 } \\
\text { 3, 神崎樋門 } \\
\text { 4. 神崎分水樋 } \\
\text { 5, 幸島大水門 } \\
\text { 6, 柿原水門 } \\
\quad \text { 外波水門 }\end{array}$ & 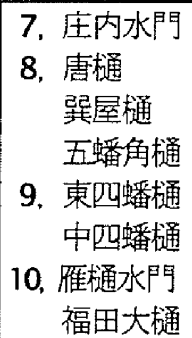 & 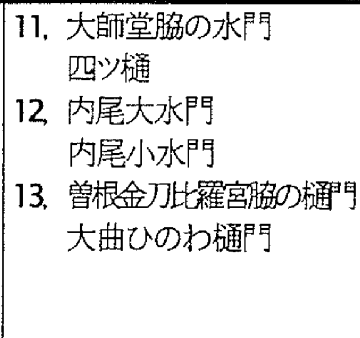 & $\begin{array}{l}\text { 14，福田古新田ひのわ樋門 } \\
\text { 15，呼松水門 } \\
\text { 16，纨水門 } \\
\text { 17，板敷水門 }\end{array}$ \\
\hline
\end{tabular}

図-1 岡山藩の干拓地の石造樋門

\section{（1）石造操門の時代的·地域的特徵}

岡山藩では、1660 年代後半から樋門の築造に石材が用 いられるようになり、1680年代から備前式の定型的なス夕イ ルに移行した。そこで、本章では、前者を初期、後者を盛期 として二つに分けて紹介する。初期樋門の代表は、現存しな いが、岡山藩初の石造樋門と推定される友信新田の樋門と、 石工・河内屋治兵衛 ( 3 章参照) が最初に築いた東片上と福 田村の石造樋門である(福田村の樋門は実態不明のため省 略する)。盛期樋門は、书板の改良が行われ大型化した石造 樋門で、備前の樋門の定型となった。干拓地の拡大に伴い、 軟弱地盤上に施工されるようになったのもこの時期の特徵で ある。

現存が確認されている干拓地の石造樋門、および、撤去も しくは改修されているがデータが確認でき本論文でも取り上 げた石造樋門の概要を、図-1に示す。 a)初期（1660年代一 70 年代）

<友信と的“新田 ${ }^{3)}$ (1664(宽文4)年、15 町 2 反 5 畧 $>$ 井田いたの小樋は、岡山藩で最古期の石造樋門と目される。 池田家文庫「御評定書」(寛文八(1668)年六月十日の条 ${ }^{4)}$ ) に、

“和気郡友信新田の确……是习石柱二仕度候、犬島二 而被仰付可被下候"

と記されているのがその根拠である。現在のところ、これ以 上時代を遡る記述は見つかっていない。この小面は、残念な がら 1976年に撤去され、写真すら残されていない。従って、 以下の記述は、史料をもとに構成したものである。

小樋は、その数年〜10 年ほど後に構築された大お甜樋と一 体化され、次ページ図-20ような構成の石樋となった。大き さは、「明和三成(1766)年 和気郡井田村樋改帳」5) 以基づけ 


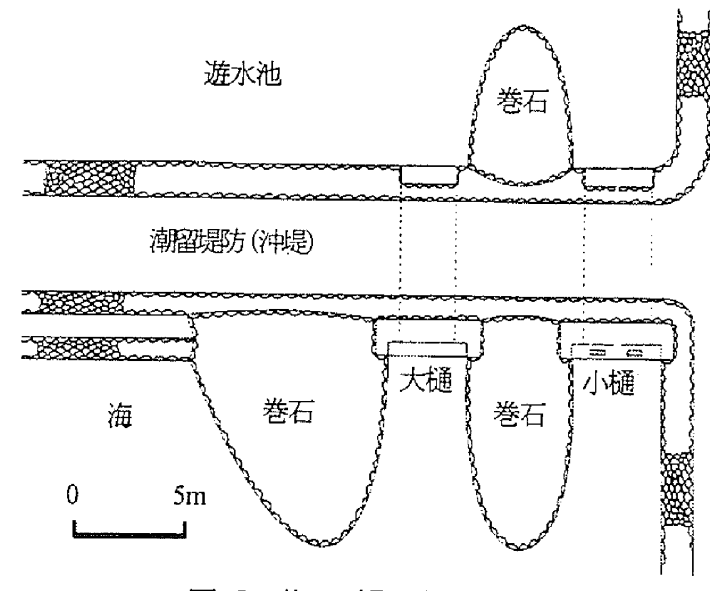

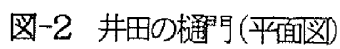

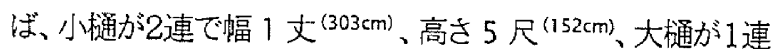
で幅8尺(242m)であった。つ並んだ両旋の間 (約3 間)には、 遊水池側て長さ約 3 間の「巻石」、海側にも長さ 5 6 間的 10m) の巻石が設けられていた ${ }^{6.7) 。 ~}$

巻石構造は、岡山藩では舟着場の施設として 1680 年頃 加ら造られ始め、1690 年代にかけて水制、洗堰、防波堤な どに広く適用されるようになったものである2）井田の場合、 小确だけでは排水能力が不足したため、隣に大樋を新設し た際代付加されたものと推測される。樋門の両䐥こ巻石導流 堤を築くことで、排水時に起こる水流の乱れの発生を防ぐと ともに、基礎部分の洗掘を防止し、硧門を保護しようとした のであろう。しかし、史料がないため築造時期は特定できな いし、現存しないため機能を正しく評価することもできない。 なお、巻石は、現地では「饅頭形」と呼ばれてきた ${ }^{8)}$

井田の小樋・大樋のその他の特徵は、両者で书板の開閉 方式が異なっていたこと(図-3，4参照)、ならびに、干拓地 でありながら岩盤上に設置されていたことである。

\section{<東片上加加（1664(寬文4)年頃、17町6反) >}

東片上の潮なお樋は、後述するように、岡山藩で最も著名 な石工・河内屋治兵衛からやへかが築いた最初期の石造樋門 の一つである。筑造時期は 1671(筧文 11)年。1664 年の新 田帳に“東片上村、高百十二石九斗一升”とあること加 9! 東片上村そのものは 1671 年以前に干拓が終了しており、干 拓当初に筑かれた木造懈門が、治兵衛により石造樋門に改 修されたものであろう。

潮檤は、井田の小樋・大樋と同じように、並設した樋門の 間に、幅·長さとも3〜 5mの「巻石」が用いられていた6)。残 念なことに、こちらも1942年と60年頃に撤去されてしまい、 絵図や写真も残っておらず、形態は不明である。小林孫七郎 「何書」(御留帳評定書) 延宝四(1676)年十二月二十一日の 条）に、“石懈内法二尺七寸 ${ }^{(81 \mathrm{~cm})}$ 四方”とあることから 10 ， 小規模なものであったことがうかがえる。

なお友信新田、東片上のいずれの地域も、地質的には流 紋岩の分布域に属し、花崗岩の産出地ではなかった。そこで、 潮留堤防には近边で採れる流紋岩が使用された。しかし耐 久性の要求される樋門と巻石には大島(後年の改修には小豆 島）産の花䟖岩が使用されたと言われている6.7)。

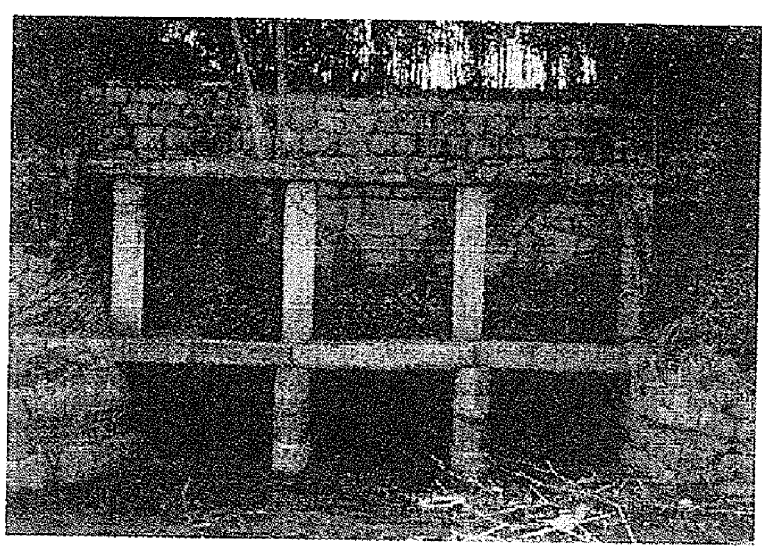

写真-1 外波水門

\section{b)盛期（1680 年代以降）}

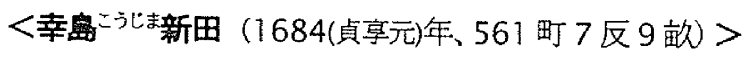
幸島新田には、神崎か心さき樋門 (5連)、幸島大秥か水門 (4 連) ”)など多連式の大型樋門が筑造された。しか、これら は現存しておらず (神崎桶門は 1965 年解体)、わずか心、 外波水門 (3連、写真-1)、柿原水門 (2連)、神崎分水樋門 (2連)の三ヶ所だけが残っている。さらに、19 世紀前半の 「定御普請御用留帳」、「幸島新田手鑑」などに“御据替”と いう記述が多数あることから 12)、これらは、現存していても 当初 (17世紀) の構造物とは限らない。現に、「定御普請御用 留帳」の「幸西定御普請場所」に“文政十二年 東水門、天 保七(1836)年 西水門”とあり、さらに、「諸御用要留書」に “文政十一子年同十二丑年 幸西東水門据替”とあることか ら ${ }^{13)}$ 、柿原水門が1829年、外波水門が 1836 年に改築され たものと思われる。

石造樋門には、設置された場所によって形態の違いが見ら れる。外波水門と柿原水門は、遊水池の潮留堤防に築造され ているため(堤防に開口部を設けたという感じで) 樋門背後 に堤防石垣が見られる。一方、神崎分水樋 (完成年不明) と 幸島大水門・小゙水門（いずれも完成年不明、現存せず、写 真あり）、、拓堤防と河川の接点に設置されているため、 橋のように石材だけで構成されている(神崎分水樋は $1.5 \mathrm{~m}$ $\times 1 \mathrm{~m}$ ほどの石積 (花崗岩)で二つに分かれている)。

\section{<沖新田（1692(元禄5)年、1918町余) >}

岡山藩最大の干拓面積を誇る沖新田の特徴は、3ないし4 連の大型の石造书門が連続して造られたという点である。 その数は、百間川の河口に 4 ヶ所 (1733(享保 18)年以前は 5 ヶ所)、百間川の西側に 4 ヶ所、東側にも 6 ヶ所もあった ${ }^{14)}$ 。 そのうち、石樋門として残っているのは西側の中四蟠桶と東 四蟠樋の 2 ヶ所だけで、それらも、明治期の改修で石材を含 めて全面更新されたものでしかない15。

沖新田で特筆されるべきものは、百間川河口の唐から樋で ある。これは 1704(宝永元)年に筑造された洪水対策用の石 造捅門で、後述するように、わが国でも最大級の 20 連とい う超大型の構造物であった (次ページの写真-2参照)。この ように大規模構造物であるにもかかわらず、樋門の構造に関 する史料は残されていない。唐书は、百間川河口水門の新 設 (1968年)に伴って撤去されてしまったが (昨年、解体石材 


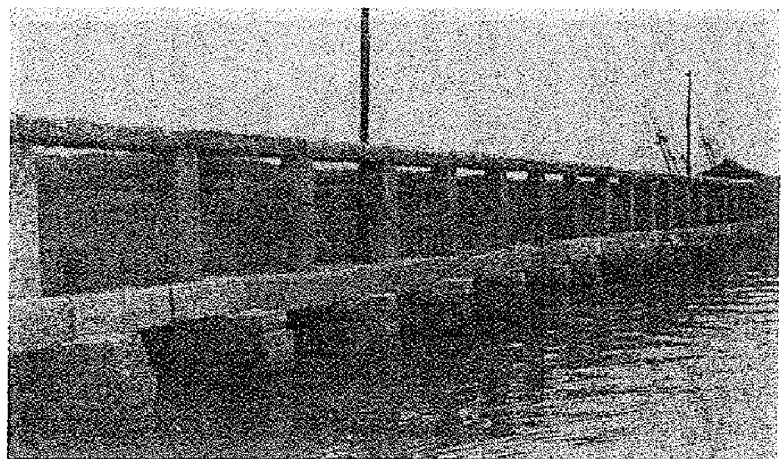

写真-2 唐樋

（出典:『沖新田開留三百年記念史』）

を使って津田永忠ながだの顕彰碑が作られた）、それすら 1892(明治 25)年の改佟時のもので、創建時の構造を知るす べはない(1892 年の報告書では、改修後の基礎工のことし か触れられていない $\left.{ }^{16)}\right) 。$

なお、百間川の河口部は広大な遊水池になっていたので、 沖新田の硧門はいずれも堤防石垣付きの構造で、石桁橋夕 イプのものはなかった。使われた石材は、児島湾をはさんだ 対岸の児島半島から切り出されたことが、投入した人夫、土 砂や他の材料の量とともに『池田家履歷略記』「元禄五年

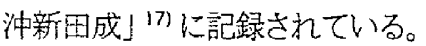

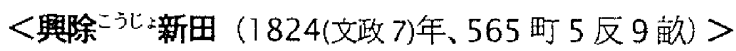
興除新田を代表する内尾うちお大お水門・小冰門 (写真3）は、現存する岡山県下で最大級の巨石樋門である。水門 は妹尾川河口にあり、いずれも石桁橋夕イプの構造物である (幸島大水門.小水門と似ている)。ともに3連ではあるが、 連数よりも、70 cm四方の断面をもつ長さ $10 \mathrm{~m}$ 花峇岩の 石梁·笠木の迫力に圧倒される”。

両水門とも創建時期は末確定である。『興除新田紀』巻 之六「樋据方之事」18)に、1821(文政4)年から1824 年まで 賎門の工事が行われたとの記録はあるものの、それが大水 門・小水門以該当するかどうか確証は得られない。当然、石 エなどに関する記述も皆無である。また、1960 年前後に、 規模・形式ともに大水門とよく似た石造樋門が撤去されたが （恐らく丙川、写真も残されている）、年代を特定する唯一の

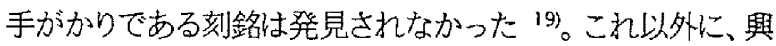
除新田には小規模な単連式の樋門が数基現存しているが、

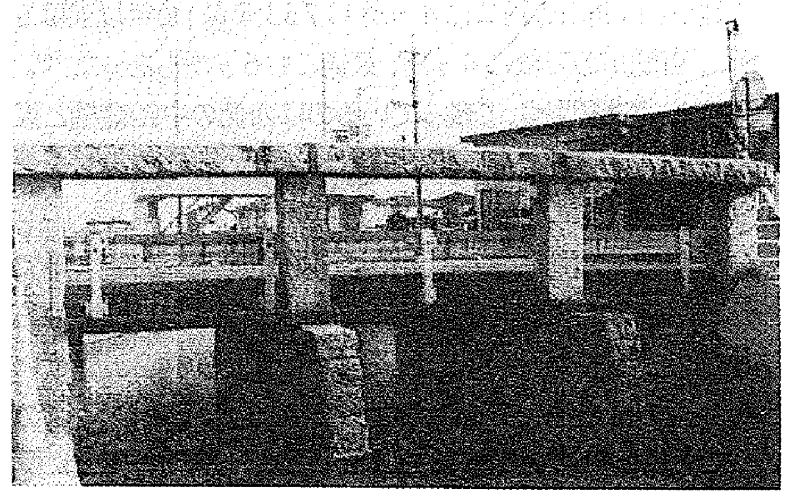

写真-3 内尾小水門
それらが『興除新田紀』の記述の中でどれに当たるのかは 特定できていない。

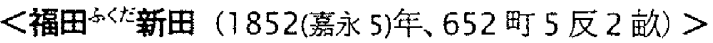
福田新田は、江戸末期に千拓された新田であることから、 創建時の埇門が現存している(㭔松よ゙まつ、板敷けししき水門)。 当時の記録も比較的残っているため、規模だけでなく、築造 方法や携わった人物も判明している。

呼松水門 (3連、1852 年)の構造上の特街は、中央スパン が雨側径間より大きくなっていることである。悀門の大きさ は “長八間四尺 ${ }^{(1576 \mathrm{~cm})}$ 内法一丈四尺四寸(739cm)”、稼㗢人只 は“石工千八百三十二人七歩 豊島石工一○二人六歩”と記 録されている 20)。水門の築造者は石工·和島屋重吉（後述） て、、“嘉永五子年 此度呼松前堰切并水門据込被仰……和 島屋重吉與島へ石見分外山主工照合二遣申度奉存"（『撮 要録』「石工和島屋重吉御用他所出带刀免」) ${ }^{21)}$ とあるよう に、彼が与島 (香川県、福田新田加仙至近距離) から石材 を取り寄せて築いたことが判明している。なお、1975 年の 改修時に、“嘉永五年 奉行梁井忠次郎” の刻銘が見つかっ た 20) (改修で一部改変されたため、堤防石垣付きタイプのも のであったか、石桁標タイプであったかは不明)。

板敷水門 (1連、1849 年、写真-4) は、幅約 $4 \mathrm{~m}$ と小規模 だが、艇門背面の堤防石垣が完全に残っており、潮留堤防に 築かれたことがよくわかる点に特徵がある。石材に“嘉永二 年 ${ }^{(1849)}$ 夏六月造” の刻銘があるほか、奉行、定手代、手代の 名前が記された文畫も確認されている22)。水門は、1995 年 に倉敷市の文化財に指定された。

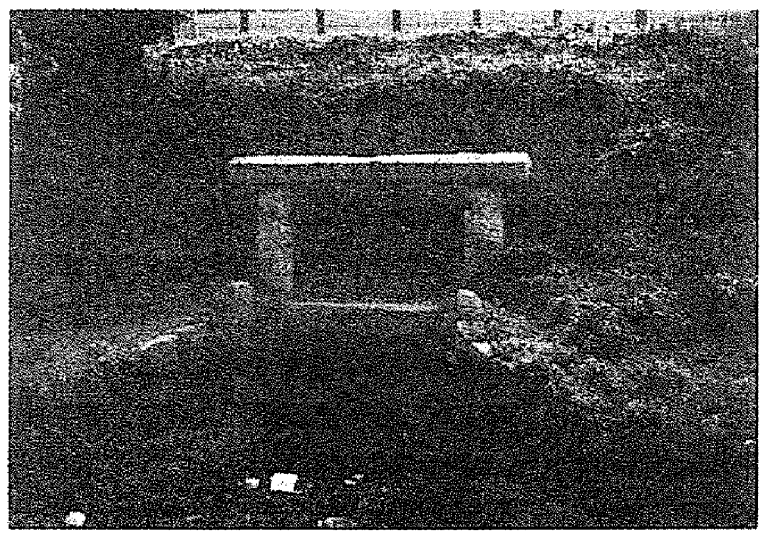

写真-4 板敷水門

丸山水門 (規模不明) は現存していないが、「福田沖御新 開丸山水門 御据込御普請諸入用控帳」が残されていて ${ }^{22) 、}$ 奉行名（加納次右衛門）、筑造方法を知ることができる。

\section{(2)石造媚門の技衡的特徽}

ここまで新田ごとに确門の特徵を見てきたが、本節では、 得板の開閉方式 (巻上式の導入)、規模 (大型化)、施工法 (軟弱地盤への対処)の三点に着目して、より詳細に構造の 変化を辿ることにしよう。

\section{a)根板開開方式}

友信新田の井田の小樋・大樋(罒-1の1)では、既に述べ 
たように、樋板の開閉方式が異なっていた。「明和三成(1766) 年 和気郡井田村樋改帳」5)によれば、小踊は、“石确 壱門、 長武間半内法横一丈高五尺片戸武枚中機有笠木也”、大线通 は、“水門 壱口、長戴間半内法八尺四方片戸関板四枚車知 木壱本……“記されている。小㭪の項にある「石书甬」とは、 「中棧」とあることから、中柱によって間口を二つに分け、梯 子状の取手で樋板の高さを別々に調整し開閉させることの できる硧門であったと思われる(図-3)。これは日常開閉 ていた书門で、後年、小樋と呼ばれるようになった。一方、 大樋の項にある「水門」とは、「車知木壱本」とあることから、

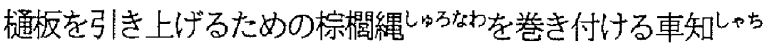

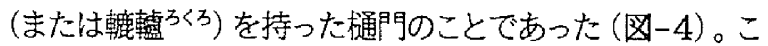
れは洪水時に使われたもので、前述したように、小樋の建設 から数年 10 年ほど経過してから増設されたものと推測し ている。

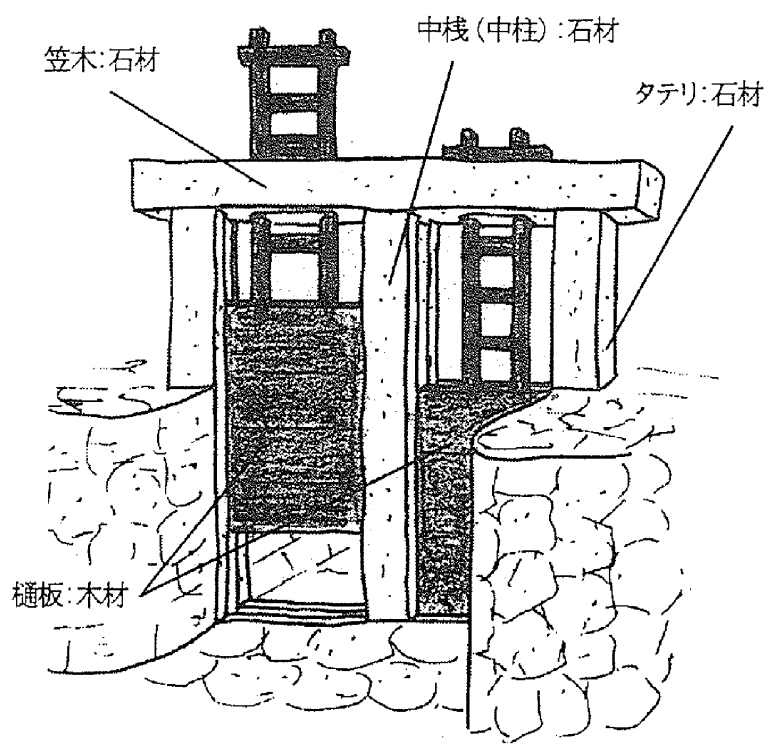

図-3 小樋(石觱)

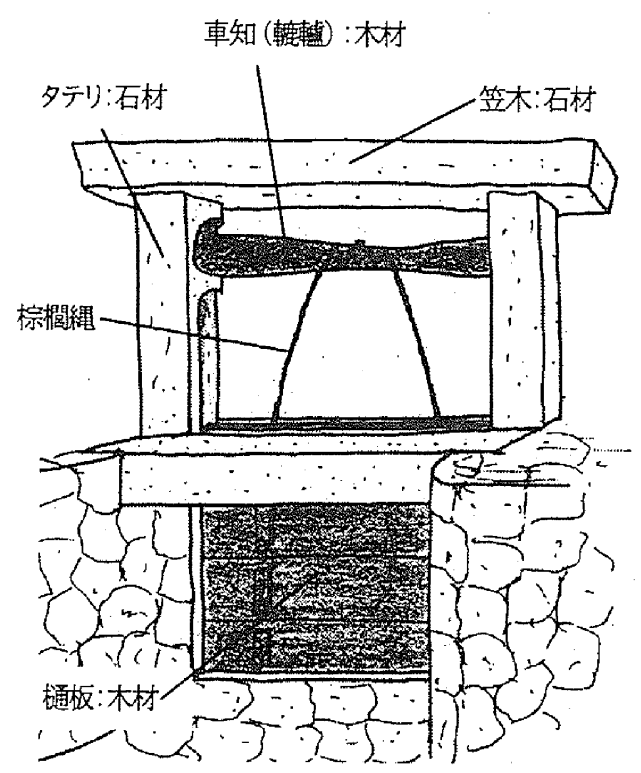

困-4 大樋 (水門)
岡山藩では、前者は、分水樋など小型の樋門で使われて いた開閉方式であるが、排水硧門に使われた例は、井田の小 樋と東片上の潮桶 (困-102) 以外には今のところ確認され ていない。後年の排水樋門では、いずれも後者の巻上げ式 が採択されているが、それは、排水効率を高めるため、幅の 広い樋板でも迅速に開閉可能な方式が必要とされたからて あろう。車知を支えるため石柱には円形の軸受け穴が穿た れ(写真-5)、幅を広くとるため石梁はより長くすることが求 められた。この方式は強度の高い花崗岩だったからこそ可能 な構造であり、岡山の石造樋門の大きな特徴になっている （備前石工が肥後・八代で技術指導した石造樋門は、高強度 の花崗岩が得られない地方が故に、岡山のものとは全く別の 形態をとっている)。

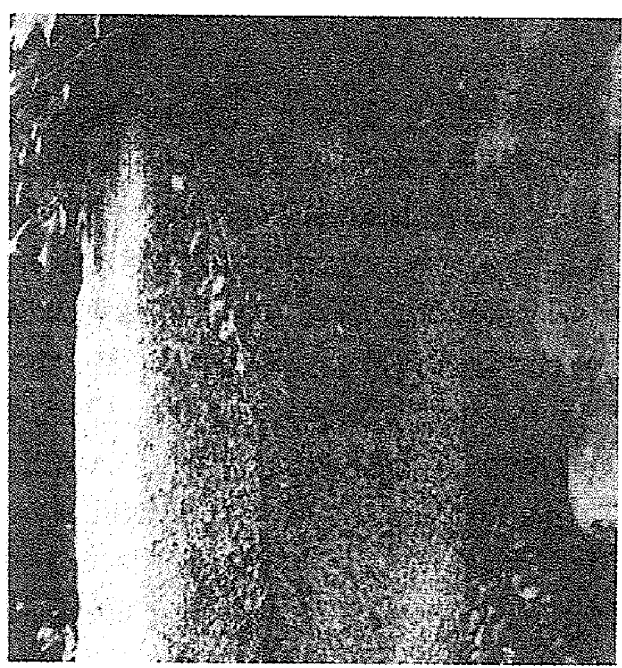

写真-5 外波水門の軸受け穴

\section{b)大型化}

干拓面積が一挙に拡大した幸島こゔま新田 (1684年)以降、 石造樋門が大型化していった。岡山藩の干拓、治水、港湾な ど土木事業を技術面で支えた普請奉行の田坂与七郎 (1647 ～1710 年) と近藤七助 (1655 1731 年) 住、遊水池と河口部 の水門を結合させ、遊水池に溜まった琹水を干満の差を利用 して排水する技術を取り入れたが 23.24)、それに伴って、干潮 時の排水能力を高めるため、スパン 2〜3m、多連式 (3〜 5 連)の大型确門が築造されるようになった。

檞門の規模が一層の大型化を見せたのが、藩内最大の沖 新田で造られた唐桶（1704 年、図-1の 8) である。沖新田の 築造にあたり(1692 年)、新田中央を流れる百間川河口部 には巨大な遊水湖が設けられ、大型樋門が数多〈造られた ${ }^{14}$ 。 しかし、1702 年の出水では、排水しきれず大洪水を引き起 こしたことから、津田永忠 (1640 1707 年) が前述の田坂. 近藤に工夫して造らせたことが、永忠の「書状」（津田央氏 所蔵)に記されている25)。唐樋は、20連、全長 50mにも及ぶ 壮大な桶門であったが26)、藩内では他にこれほど大きな石造 硧門が造られることはなかった。

1680 年代以降、干拓面積の拡大に伴い、背後に大きな遊 水池を有する場所での石造桶門は大型化していったが、排 水量の少ないところでは、板敷水門（図-1の17）のように単 
連のものが相変わらず用いられた。

\section{c)基磲の施工法}

巨石を駆使した石造樋門を軟弱な地盤上に築くことは困 難な作業であったことは想像に難くない。最古の石品通である 井田の小檤の場合、友信新田内でも山際の岩盤上に樋門が 築かれている。それは、できるだけ地盤の安定した場所に石 樋を築こうとしたためであろう。池田家文庫「御評定書」 （寛文八(1668)年六月十日の条）以は、“和気郡友信新田の樋、 岩习切拔申候” 4) と記されている。1976年の解体では、岩艋 を掘削しただけでなく、「か极つちと呼ばれる棣喰で突き 固めて基璴部分を整形し、その上に樋閏を築いていたことも

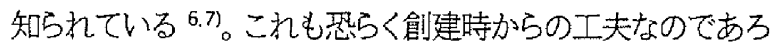
う。犮通門がより大型化する幸岛新田でも、石造樋門は、西幸 島·東幸島の山際 (干拓される前は、島の部分) に築かれて いた。

新田開発が大型化し、より大きな海面を干拓する必要が 生じ、沖合に締切堤防を築か齐ばならなくなってから、基礎 工事が進化を遂げる。石樋の施工の際、胴木を用いることに よって軟弱地盤でも築造可能なように工夫されたのは沖新 田 (1692 年) 以降と考えられる。巽屋樋、五蟠角嗵 (図-10) 8) の場合、太さ $20 \mathrm{~cm}$ の丸太を $90 \mathrm{~cm}$ 間隔で格子状に並べ、 その間に浗喰を流し込んだ胴木を用いていたことが、撤去時 (1968年) の図面 ${ }^{27)}$ から読み取れる。これら二つの樋門はい ずれも明治期に改修されているため、漆喰の流し込みに対し ては創建時のものかどうか疑問が残るが、胴木そのものは恐 らく創建時からのものであろう。岡山藩の石樋を描いた『水 門組立之図』(写真-6) ${ }^{28)}$ には胴木の絵が 4 枚収録されて いるし、『興除新田紀 巻之六「四 桶据方之事」(文政四辛 巳 巳 $^{(1821)}{ }^{18)}$ に“樋木·松丸太御林入用次第”と記され、さらに、 「福田沖御新開丸山水門 御据込御普請諸入用控帳」には土 留方法などとともに、“胴木長拾間横六間敷根太長横共右同

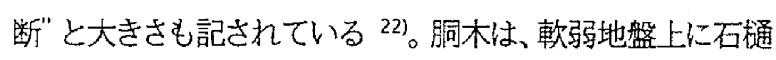
門を筑く上で不可欠の技術であった。

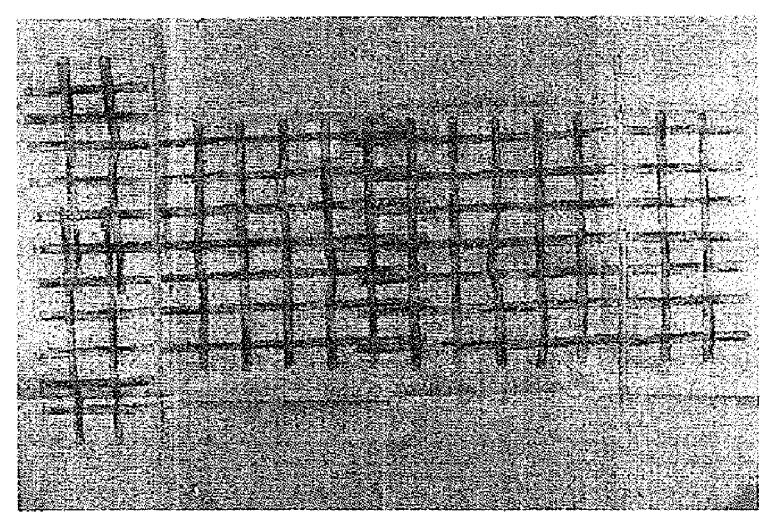

写真-6『水門組竞図】（池田家文庫）

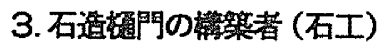

本章には、石造樋門の筑造者（石工）に関して史料にどう 記述されているか調査した結果を示す。近世の利水事業に 関する史料としては、池田家文庫に所蔵される「御留帳評定
書」をはじめとする文献群の他 (参考文献・注橎の冒頭に記 した池田家文庫の解題を参照されたい、、庄屋や桶守の家に 伝わる文書なども対象となると思われるが、石工の記述を探 してゆくと、池田家文庫に出典が限定される結果となった。

なお、本章の(1)節では、石造樋門の築造に最大の功労の あった石工・河内屋治兵衛の経歷と業績、(2)節では、河内屋 治兵衛の後継者について述べる。

\section{(1)河内屋治兵衛}

河内屋治兵衛は、藩政初期の大事業の大半を手がけた津 田永忠の下で施工の実務をこなした技術功労者として知ら れている。本節では、治兵衛の最初の石造樋門とその高かっ た評判 (迅速な普及)、藩のお抱え石工への登用について見 てゆく。

\section{a)最初の石造整門}

河内屋 (旧姓·吉富) 治兵衛は、1666(筧文6)年、岡山藻の 大横目 (大目付) ·津田永忠によって藩主・池田家の和意谷 Wた墓所の造営を担う石塔石工として大坂 (泉州) から招か れた 23.29\%。招かれた経緯は知られていないが、この造嘗によ って石工としての技術が高く評価され、岡山に 30 年以上も 留まることになった。『池田家履歷略記』「寛文七年 和意 谷成」 ${ }^{30)}$ (治兵衛の名が出てくる唯一の項)には、次のように 書かれている。

\section{“和意谷碑石其外石の事に付き大坂の石工治兵衛と云 者備前に下り細工せしか同十年に至皆済に及ひ大坂 に帰らんとせしに治兵衛元来妙工なれはまつ備前に 在て諸士の碑石等をもきらせ然るへき者なるよし… …備前にと〉まり高自北浦なとにて石多く割らせ置れ 諸士の用に当られしなり”}

石塔石工の治兵衛がなぜ石造樋門を手掛けるようになっ たのか㤝、史料が見つかっていないためわからない。しかし、 招致の 5 年後には石造樋門を築いている。柴田一氏は著畫 『津田永忠』 ${ }^{29}$ ) の中で、治兵衛の「書付」(池田家文庫「御 留帳評定書」延宝四(1676)年十二月二十一日の条)を紹介し ている。

\section{“御野郡福田村·和気郡東片上村右両所之石樋被為仰 付候処二、只今迄少も狂無御巫候、右両村之庄屋衆. 百姓其節申候八、今ノ分二て以来石/狂も無之候は、 後々八所々八樋不残石桶二改可申上と申候、右潮土 手之石硧さえくるい不申候へ八、并㵾之分木又八池 书なと八猶以狂申間敷候間、已後は弥可被為仰付と 奉存、諸手/石御用仕迴申、当八月より以来、於児島 二石取仕せ、大分之御石割置申候”}

そこでは、「治兵衛が施工した御野郡福田村 (岡山市) の石樋 （図-1の 10)、和六郡東片上村 (備前市) の潮桶 (図-1の2) は少しも狂いが発生しなかったので、他の樋門もすべて石造 樋門に改修して欲しいと庄屋や百姓が依頼していること」、 および、「用水の分水桶や池樋も含め、今後の增加する改修 
に対応するため、児島 (岡山市)で大量の石を切り出していた こと」が自己評価の形で申告されている。

東片上の潮樋に関しては、「御留帳評定書」(延宝五 ${ }^{(1677)}$ 年の条)にも、“和気郡二テ申付侯石桶当年迄六年コ夕エ申 候由申候”と記されている 10\%。従って、その筑造時期は 1671 年で、治兵衛が手がけたことが明らかな最初の石造樋 門と位置付けられる。

しかし、上記の記載からは、治兵衛が自ら石造樋門を考案 したかどうかは不明である。河内で見聞していたかもしれず、 あるいは、岡山へ来てから何らかのヒントをつかんだかもしれ ないが、先の「書付」以外に治兵衛が自ら記した文畫は見つ かっていないため、これ以上のことはわからない。

さらに、2章で記したように、岡山藩最古の石造樋門と位 置付けられているのは友信新田の井田の小樋 (1668 年)であ り、東片上の潮书 (1671 年)に3 年先行する。井田の小檤と、 東片上の潮通との関連は全く不明で、双方とも治兵衛の作か もしれないし、治兵衛が小樋を見て潮通を造ったのかもしれ ない。ただ、万一小樋を治兵衛の作と考えても、彼の来岡 (1666 年) 後のことであり、矛盾は生じない。

\section{b)石造䗠門の効用}

こうして導入された石造樋門は絶大な信用を勝ち得た。 木造确門と石造樋門の耐久性に関して、小林孫七郎の「伺 書」(「御留帳評定書」延宝四(1676)年十二月二十一日の条) には、以下のように書かれている10。

“東片上村潮桶、唯今迄一䁬御座候得共、歩分二テハ 洪水之節悪水吐兼申二付、御物成度々捨少申候。石 樋今一噮居申度奉存候。……石屋治兵衛二積仕七候。 ……栮樋二テ三年ハコ夕工兼申候”

すなわち、「東片上の潮樋は一つしかなくこのままでは洪 水時に排水しきれない。木造硧門では 3 年ももたないので、 石造樋門を治兵衙に築造して欲しいと頭い出ている。こう して石造樋門の耐久性の高さが認められると、1677(延宝 5) 年に“邑久放・御野和。肾島潮樋”、翌年 1 月に“御野郡潮汐 堤䞻”として 9 ヶ所、2 月に“上道郡松崎新田村 (岡山市)”の 2 ヶ所（図-1の 7)、と木造樋門を石造硧門に改修する決定 が次々と評定所で下されていった ${ }^{10)}$

石造蝷門への改修に際しては、耐久珄のほか心、築造経費 も大きな影響を及ぼすはずである。もし、木造樋門に比べて 石造樋門が遙かに高価についたのなら、敢えて石造化は行 われなかったかもしれない。ところか゚、「賞賜付賑給」(池田 家文庫「留帳」延宝五年の条)には、

“当春邑久. 御野. 児嶋三郡之石桶積上ケ之通御銀被遗 候処、作廻能仕、一貫目余差上申候。不被仰付候処二 石樋之積り木樋同前之御物入二仕度卜積上ケ候。奇特 二思召御榱美二被下ル"

とあり、木造檤門と石造樋門とが同一コストで築かれたことが わかる ${ }^{10}$ 。岡山が花崗岩の座地で石材が安価に入手でき、 輸送コストも安く済んだため、石造樋門を低廉な価格で築く
ことができた。その上啝久性は半永久的であったから、藩内 の樋門がことごとく石造化されたのは当然の帰結であった。 そして、それとともに、治兵衛の名も上がっていった。

\section{c)お抱え石工、そして、死}

河内屋治兵衛は、それまでの石造樋門への改修実績が高 く評価されたために、普請事業に携わる藩のお抱え石工とな った 23.29) (時期不詳)。彼は岡山城下に屋敷を与えられ、給 米四拾五俵五人扶持をもらい(下級藩士のレベル)、帯刀も誥 された(『市政提要』「石細工之事」31) および「御留帳評定 書」29))。

治兵衛は石工の統括者として、普請事業を次々とこなして ゆく一方で、後継者の養成にも怠りなかった ( 2 節参照)。彼 が藩に提出した「書付」(「御留帳評定書」延宝四(1676)年十 二月二十一日の条)では、次のように訴えている29\%。

“然処二時二より三ヶ所も五ヶ所も一同に御用被為仰付、 左様之節は常々手前二抱置申弟子斗沉ては手支二而御 用遅々仕候間、俄二上方え石切共雇に遣シ申候”

「増加する普請事業に対応するには今の弟子だけでは不足 するので、上方から雇い入れたい」とする申し出であるが、 この文面などから、港湾整備や新田開発など多くの普請事業 に、岡山の石工ではなく河内の石工集団が活躍したこと、換 言すれば、「地元の石工は育てなかった」と指摘する研究者 もいる29)。

治兵衛の晚年は、はっきりしていないが、『市政提要』311 に“享保八(1723)年二右次兵衛退身仕申候二付”とあることか ら、1723 年まで岡山にいて大坂へ帰ったとするのが通説 29) とされている。ただ、妻の墓石と並んで“元禄十一戌寅(1698) 年”と刻まれた治兵衛のものらしき墓が発見されている ${ }^{32) こ ~}$ とから、それが 100\%確かとも言い難い。もし後者が本物の 墓であれば、治兵街が岡山にいた年限は 25 年も短くなる。 彼が携わったとされる事業で、この年限に引っかかる代表的 なものは、閑谷しず比学校の石摒せさい（1701 年、備前市)であ る。その巻石の美しさは、曹源寺の石階段の側石 (1698 年以 降、剛山市) とともに、百間川の荒手 (1687 年、岡山市)、大多 苻施执岛の元禄防波堤 (1698 年、日生町) など一群の曲面石 積の中でも極めて完成度の高いものである。彼が 1698 年に 死亡したとすれば、藩のお抱え石工の中に高度な技術が蓄 えられ、それが治兵衛後にも受け継がれていたことを物語っ ている。

\section{(2)治兵衛の後林者}

河内屋治兵衛の後継者については、史料が少ないことに 加え、治兵衛ほど話題にされることが少なかったため、その 全容をつかむことは難しい。

河内屋治兵衛の後で活躍した石工は、河内屋治良兵衛 (生没年不詳)と目される。彼が携わったことが判明してい る唯一の普請が、神崎通門 (5連)（図-1の3）の築造である。 喼門が撤去 (1965 年)された際、“享保甘(1735)年十一月 据 替 作者 石屋治良兵衛“の刻銘の入った石材 ${ }^{33)}$ が発見さ 
れたことがその根拠である。治良兵衛の普請は、治兵衛が 1687 年に築いた 4 連の旛門を5連に改修したもので34)、“貞 享四(1687)年五月 作者 石屋治兵衛”と刻まれた石材 33 も无同 時以発見されている。

それ以外の打抱え石工については、1803(㚖和3)年に鳥取 屋武介 (生没年不詳) が、「乍恐口上書付」(『市政提要』 「石細工之事」31)に記した内容が手がかりとなる。

\section{“右次兵衛退身仕申候二付、諸御用私共親鳥取屋長介 義御郡会所元森川助左衛門㥞・浦上十右衛門样被為 遊、次兵衛跡御用私先之親共之被為仰付難有奉存舆 候、勤方之義八先々之通御城内并御出馬御国替等二 屯御供可任段被仰渡、追て八次兵衛通二御給御扶持 共可被仰付"}

すなわち、治兵衛が退いた後、鳥取屋長介(生没年不詳、 「鳥取」は大坂の一地名）が跡を継ざ、同じような待遇を受 けてお抱え石工を勤めていたことがすかる。また、“右次兵 衛義先々親共従弟二も相当り申候二付紐工物事も相伝”と、 治兵衛との関係、技術の伝授についても指摘している。

また、20 年後の1822(文政 5)年に書かれた「奉影上」 (『市政提要』「石細工之事」311)）により、お抱え石工が鳥 取屋議介から和島屋重吉（治兵衛の従稊の孫）に代わったこ とが知られる。この和島屋重吉は、1852(察永 5)年に呼松水 門（図ー1の15）を築造し、带刀を許されたことが、『撮要 録』「石工和島屋重吉御用他所出带刀兔」 ${ }^{211}$ に記されてい る。

河内屋治兵衛が最初に石造桶門を築造してから約 200 年 を経た江戸末期においても、その技術は萔え石工が握って いた。時代は遡るが、1716(正徳 6)年の「児島郡福田村新田 䫓書写」に㤬、大庄屋によって開発された福田古新田でも、 樋門（図-1の 14）の築造だけは藩に依頼したと述べられて いる ${ }^{10}$ 。幸島新田では、地元で楖門の修理を行っていたが、 技術が稚拙で、年数の経過により修理筒所が多くなったため、 藩に依頼していることが、御内意口上 文政二叨(1819)年指 上にに記されている35。

以上、断片的ではあるが、入手可能な史料沉準じて岡山藩 のお抱え石工の系譜と藩との関係を再構成してみた。岡山 藩は江戸期を通し、河内幄治兵衛の係累の大坂石工をお抱 え石工として重用した流れが見えてくる。こうしたテクノクラ 一十の存在があって、岡山藩の普請事業が可能となったこと もまた事実なのであろう。ただ、この流れから地元の石工は 除外されてしまったかのように見える。ところが、備前の石 工」は、人の移動が限られていたにも限らず岡山以外でも活 躍していたことが知られている。石ア一チの本場・肥後の国

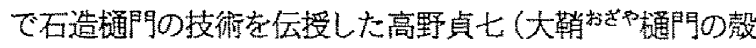
桶、八代市、1819 年) や、函館·五稜郭の石垣築造 (1859 年) に加わった井上喜三郎らの名前が上がっている。藩命で派 遣されたこれらの石工楝梁と、治兵衛一派のお抱え石工との 関係は現段階で注全くわからない。

\section{4.まとめ}

本論文では、現存する石造樋門と併せて、古文書を中心に 古写真、殓図など史料の分析をもとに、石造桶門とその築造 者（石工）について述べてきた。得られた結論を二つにまと めて記すと、それぞれ、次のようになる。

\section{<石造姆門>}

（1）基本構造注、1660年代後半に、木材加万石材に急速加 非可逆的に変化した。

(2)排水能力の不足を補うために樋門を增併設する場合には、 巻石構造の導流堤が築かれた (場合がある)。

(3)书板の開閉方式は、花崗岩の特性を活かし、巻上げ式に 変更された。

(4)1680 年代の干拓の大規模化に伴い、排水能力の高い多 連式の樋門が築造された。

(5)基礎工事に関しては、1690 年代以降に、軟妈地盤での施 エが一般化した。

\section{<石I>}

(1)石造楅門の真の考案者は特定できないが、河内屋治兵衛 は筑造者 (施工者)として多大の賈献をなした。

(2)岡山藩は、河内屋治兵衛を活じめとする大坂石工を抒抱 え石工として重用した(石造熥門の筑造は藩のお抱え石 工が担当した。

本論文では、石造㭪門の変化、石工の系譜を概観すること はできたが、設計・施工過程の分析には至らなかった。今後 は、膨大な記録を収める池田家文庫の中で、技術解明の参 考になる史料の整理・分析を進めることに加え、庄屋文書や 石工の家系に残る記録の発掘も必要となろう。岡山藩の場 合、樋門に建造年代や石工名が刻まれている例は少なく、後 年に改㣠された可能性も多いため、史料で特定されない限り、 建造時期や石工名を特定することは困難である。従って、現 存するものに関しては、年代特定の大きな手がかりとなる加 工の精度、産地の違いによる石材の風化程度などの分析も 必要となるであるう。

現段階では、江戸期に開発されたすべての新田の調查が 終了しているわけではない。今後は、干拓地だけでなく用水 路も含めて史料、特に絵図を参考认現地調查を行い、石造樋 門の有無（江戸末期から近代の改修も含む）の確認を行うこ とが急がれる。

なお、本論文で使用した図・写真恃、いずれも著者によっ て作成·撮影されたものである。

\section{毁碚}

就实女子大学・柴田一教授には、その研究成果を参考にさ せていただくとともに、懇切なご教示を舓った。花岡土郎氏 (備前市)には快く友信新田の調查に協力していただいた。岡 山市社会教育部文化課の根木修氏、政田孝氏(和気町)、片 山良和氏 (岡山市)には、樋門・石工に関する資料を提示して いただいた。また、該当する书守の方々にもお世話になった。 ここに記してより感謝の意を表します。 


\section{参考文献・注橎}

リストの提示の前に、本論文でしばしば用いられる池田家 文庫の構成について触れよう。

最も多く引用している「御留帳語定畫」は、藩政の最高機 関である評定所においてなされた討議を、日付ごとに書き留 めたものである。内容は多肢にわたるが、普請に関わるもの もかなり含まれ (1割程度)、一部には石造桶門や石工に関 する記述が入っている。その記載内容によって岡山藩政史が 詳細に解明されており、史料としての信頼性は高い。

『池田家復歷略記』は、岡山藩における出来事を編年体 で記した書物である。継年的に出されたものではなく、寬政 年間など数回にまとめて編集されたため、年代に若干の間違 いは見られるが、詳細な情報を得ることができる。

『市政提要』は、岡山の城下町における商工業に関する町 方史料で、この中に、石工に関して記された「石細工之事」

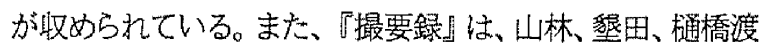
守、番所など地方(他心)関係の史料で、「雑事之部」に石工 に関する記録が取かられている。両者とも，調山藩の留帳方 によって時期を区切って編箱されたものであり、収録内容に 対しては吟味·娭討が必要である。

1)「岡山の農業用水門一児島筫干拓地と高梁川水系の用 水路以残る土木遗産群」：馬場俊介・樋口輝久. 石原 盛人: 土木史研究.vol.17、1997、pp.227-234

2）「西日本石造文化圈における「巻石」構造物一岡山県を 中心とした実態調笪」：樋口輝久.馬場俊介、士木史 研究、vol. 18、1998、pp.363-372

3）1671 (寬文 11) 年、友信新田は「井田」に改称された。

4) 『御評定書』備作之史料 (三)：備作史料研究会、1986、 pp. 5

5)「明和三戌年 和気郡井田村樋改帳」：延原家文畫 (備 前市歷史民俗資料館所藏，1766

6) 花岡士郎氏のヒアリングによる。

7) 井田の (元) 樋守·藤原氏他 2 名へのヒアリングによる。

8)井田』：井田開田三百年記念事業実行委員会、1990、 pp. $77-78$

9)『片上町史』：桂又三郎·横山音、片上町史編箘委員会、 1951, pp.73

10)『岡山県農業土木史』: 岡山県土地改良事業団体連合 会、日本文教出版、1966、pp.815-817

11)『幸島村史』：幸島村史刊行会、1972、pp.296

12)『邑久郡史』：小林久磨雄、邑久郡史刊行会、1954、 pp.57·65·336、および、前揭 11)、pp.114·148170

13) 前揭 11)、pp.160 -163

14)百間川の歷史』：岡山工事事務所、1978、pp.37

15）沖新田の (元) 樋守·过氏のヒアリングによる。

16)『沖新田開墾三百年記念史』：沖新田開墾三百年奉賛 会記念史編集委員会、1995、pp.480-482

17)『池田家履揫略記（上）』（斉藤一興、寬政年間）：日 本文教出版、1963、pp.545-547

18)『岡山県史（近世編纂物）』: 岡山県史編篡委員会、 1981、pp.234-236

19）石造樋門を撤去した石材屋のヒアリングによる。

20)『史上の福田・福田の伝説（8 福田古新田記）』：高橋 趁、福田史談会、1983、pp.74-75

21）『撮要録（下）』(徳田均平、1868）：日本文教出版、 1965,pp.2006

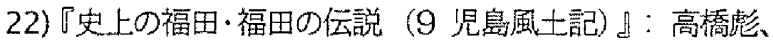
福田史談会、1985、pp.37-46

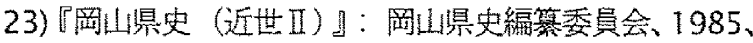
pp.209-211

24）前揭 11)、pp.291

25)『池田光政公伝（上）』：石坂善次郎、1932、pp.609

26）前揭 16)、pp.444-445

27)『百間川改修誌』：岡山工事事務所、1985、pp.155159

28）『水門組立之図』（池田家文庫）：岡山大学付属図書館 所藏 [T7-57]、年代不詳

29）『津田永忠（下）』：柴田一、山陽新聞社、1990、 pp. 169-173

30) 前揭 17)、pp.352-353

31) 汸韦政提要（下）』（寛文～万延年間）：岡山大学池田 家文庫等刊行会、1974、pp.412-413

32）政田孝氏によって河内屋治兵衛夫婦の墓が東山墓地 (岡山市)で発見された。妻の墓碑には、「大坂で生ま れ吉富(河内屋) 治兵衛と結婚した後、岡山に来た!と 刻まれていた。

33）新嗵門の脇ここれらの石材が碑として設置されている。 34）邑久町史』：邑久町役場、1972、pp.177

35）前揭 11)、pp.150-157 